\title{
Jesus, The Prophet, The Messiah, and The Host: An Interpretation of Luke 24:13-35
}

\author{
Pancha W. Yahya* \\ *Dosen penuh waktu bidang Perjanjian Baru di Sekolah Tinggi Teologi SAAT Malang dan sedang menempuh \\ studi doktoral dalam bidang Perjanjian Baru di Trinity Evangelical Divinity School, AS.
}

Email: pancha.yahya@seabs.ac.id

\begin{abstract}
The story of Jesus' encounter with two disciples on the journey to Emmaus is a unique story, among which is the story contains the question: what really made two disciples not recognize Jesus?, and why after inviting Jesus to their home, the identity of Jesus was recognized. Many solutions have been offered to answer these complicated problems, but it seems that the answers proffered are less than convincing. According to the author, the Emmaus story must be seen from the entire book of Luke and Acts because in this episode there are important themes scattered throughout Luke's two writings. The two disciples are representatives of Jews who cannot understand that the Messiah must suffer, be crucified, and be resurrected. What made them recognize Jesus again was when Jesus entertained them to eat? It was because it reminded them of a similar event before Jesus' death and at the same time referred to the role of Yahweh as the host of His OT people and the hope of an eschatological meal. In the end, the theme of this dining table fellowship became important in the Acts of the Apostles in relation to Jewish and Gentile relations within the early church.
\end{abstract}

Keywords: Emmaus, Motif of Ignorance, Table Fellowship, Rejected Messiah

Abstrak: Cerita perjumpaan Yesus dengan dua murid dalam perjalanan ke Emaus merupakan kisah yang unik, di antaranya adalah kisah ini mengandung pertanyaan: apa yang sesungguhnya membuat dua murid tidak mengenali Yesus dan mengapa setelah mengundang Yesus ke rumah mereka, identitas Yesus tersingkapkan. Banyak solusi telah coba untuk ditawarkan untuk menjawab persoalan pelik ini, namun sepertinya jawaban-jawaban itu kurang meyakinkan. Menurut penulis, kisah Emaus harus dilihat dari keseluruhan kitab Lukas dan Kisah Para Rasul karena di dalam episode ini termaktub tema-tema penting yang tersebar di sepanjang dua tulisan Lukas itu. Dua murid merupakan perwakilan orang Yahudi yang tidak dapat memahami bahwa Mesias harus menderita, disalibkan, dan dibangkitkan. Yang membuat mereka mengenal kembali Yesus adalah ketika Yesus menjamu mereka makan, karena itu mengingatkan peristiwa yang serupa sebelum kematian Yesus sekaligus merujuk pada peran Yahweh sebagai penjamu umat-Nya dalam PL dan harapan akan jamuan eskatologis. Pada akhirnya, tema persekutuan meja makan ini menjadi penting dalam Kisah Para Rasul dalam kaitan dengan relasi Yahudi dan non Yahudi dalam gereja mula-mula.

Kata-kata kunci: Emaus, Motif Ketidaktahuan, Persekutuan Meja Makan, Mesias yang Ditolak 


\section{Introduction}

The Emmaus episode is a remarkably unique pericope in the New Testament. First of all, the importance of this passage to understand the gospel of Luke and the book of Acts is undeniable. ${ }^{1}$ Furthermore, François Bovon asserts that this passage functions as both the summary and the conclusion of Luke. ${ }^{2}$ In these twenty-three verses, Luke addresses some important themes of his two volumes of works, such as the journey motif, the Old Testament prophecy of Jesus, Jesus as the rejected prophet, the death and resurrection of Jesus, and the table-fellowship. Yet in spite of its significance, this pericope is enigmatic. Reginald H. Fuller points out that the episode of the Emmaus disciples is mysteriously incomprehensible. ${ }^{3}$ Some of the conundrums that have been debated among the New Testament scholars are as follows. Why does Luke narrate a story that is the longest among three stories of Jesus post-resurrection appearance in his gospel, which includes a disciple whose name, Cleopas, only occurs once in the entire New Testament? ${ }^{4}$ Even more than that, why was the other disciple encountered by Jesus unnamed? Additionally, what made the disciples fail to recognize Jesus? Finally, what causes the two disciples suddenly to identify Jesus?

Many have proposed their solutions for this riddle. For example, Adelbert Denaux argues that in this passage as well as in the entire gospel, Luke portrays Jesus as a stranger following

${ }^{1}$ E.g. Arnold Ehrhardt, "Disciples of Emmaus," New Testament Studies 10.2 (1964): 182; Walter L. Leifeld, "Luke," in The Expositor's Bible Commentary, ed. Frank E. Gaebelin, vol. 8: Matthew, Mark, Luke (Grand Rapids: Zondervan, 1984), 1050.

${ }^{2}$ François Bovon, Luke 3: A Commentary on the Gospel of Luke 19:28-24:53, ed. Helmut Koester and James E. Crouch, Hermeneia: A Critical and Historical Commentary on the Bible (Minneapolis: Fortress, 2012), 368.

${ }^{3}$ Reginald H. Fuller, The Formation of the Resurrection Narratives (Minneapolis: Fortress, 2007), 104.

${ }^{4}$ In fact, this passage is the most detailed and elaborated narrative of resurrection appearance is the New Testament. See Huffman, "Emmaus among the Resurrection Narratives," 215. a Hellenistic paradigm of gods visiting humankind in order to save them. ${ }^{5}$ Bogdan G. Bucur has provided another explanation. He maintains that in light of Second Temple traditions, the Lukan narrative of the Transfiguration, Mark's longer ending, and the Liber Antiquitatum Biblicarum, Luke shows that Jesus has entered in the state of glory, while the two disciples have not yet. ${ }^{6}$ Furthermore, Joseph A. Grassi asserts that this narrative should be read from the light of the Eunuch episode (Acts 8:26-40). By studying both passages carefully, he concludes that in this pericope, Luke stated Jesus as the representative of traveling apostle in the early church. ${ }^{7}$ However, it seems to me that those explanations are not convincing. As mentioned above, the Emmaus account is the summary and the conclusion of the gospel of Luke. Furthermore, this passage also functions as the bridge between the story of Jesus and the story of his disciples as witnesses. ${ }^{8}$ Therefore, the only convincing way to understand the Emmaus passage is to see it in light of both Luke and Acts. In this article, I will demonstrate that some central themes in this passage also exist in many places of Luke and Acts; for instance, the ignorant motif, the suffering Prophet that is "powerful in his words and deeds," and the table-fellowship. I argue that the two disciples are representatives of the Jewish people who cannot understand that the Messiah must suffer, be crucified, and be resurrected. The catalyst of their recognition of Jesus and the God's salvation plan is the action of Jesus as

\footnotetext{
${ }^{5}$ See Aderbert Denaux, "A Stranger in the City: A Contribution to the Study of the Narrative Christology in Luke's Gospel," Louvain Studies 30.4 (2005): 255-75.
}

${ }^{6}$ See Bogdan G. Bucur, "Blinded by Invisible Light: Revisiting the Emmaus Story (Luke 24,13-35)," Ephemerides Theologicae Lovanienses 90.4 (2014): 685-707.

${ }^{7}$ See Joseph A. Grassi, "Emmaus Revisited (Luke 24:13-35 and Acts 8:26-40)," The Catholic Biblical Quarterly 26.4 (1964): 463-67.

${ }^{8}$ Also Robert C. Tannehill, The Narrative Unity of Luke Acts: A Literary Interpretation, vol. 1: The Gospel according to Luke (Philadelphia: Fortress, 1990), 277; Joel B. Green, The Gospel of Luke, The New International Commentary on the New Testament (Grand Rapids: Eerdmans, 1997), 832. 
the host for them. This action as the host is a retrospect of what Yahweh has done as the host of Israel, the manifestation of the kingdom of God that has already come, and the anticipation of the coming eschatological banquet.

\section{The Source of the Emmaus Story}

Even though this episode has no parallel in other gospels, the discussion of its source is disputable. Some scholars argue that this story is a legend. For instance, Hans Dieter Betz categorizes this account as a "cult legend" that contains internal Christian reflection. $^{9}$ According to Walter L. Leifeld, the objection to the historicity of the Emmaus story is closely related to the refusal of the resurrection of Jesus and the miraculous work of Christ. ${ }^{10}$ Others maintain that the Emmaus account is independent of Lukan writing and is later inserted into the third gospel. ${ }^{11}$ Another view is that this story was an oral tradition that has circulated among the early church before the writing of the third gospel. Luke employs this tradition and then adapts it. One of the reasons for this view is that, according to Bovon, this episode has some features of an oral tradition. Bovon also says this passage's literary style and vocabulary seem not to come from Luke. ${ }^{12}$ Furthermore, the existence of a similar story at the end of Mark confirms that this story belongs to previous oral tradition ("After these things he appeared in another form to two of them, as they were walking into the country. And they went back and told the rest, but they did not believe them;" Mark 16:12-13). Regarding the source of the Emmaus account, I would argue that it was originally from Luke because, in contrast to Bovon, the literary, thematic, and vocabulary features of this passages are identical to that

${ }^{9}$ See Hans Dieter Betz, "Origin and Nature of Christian Faith according to the Emmaus Legend," Interpretation 23 (1969): 34-35.

${ }^{10}$ Leifeld, "Luke," 1054.

${ }^{11}$ See e.g. Ehrhardt, "Disciples of Emmaus," 182; Huffman, "Emmaus among the Resurrection Narratives, 219."

${ }^{12}$ Bovon, Luke 3, 369. in the rest of the Lukan writings. ${ }^{13}$ Concerning the occurrence of a similar story at the end of Mark, it is widely believed that Mark's ending was added to the gospel of Mark later. Thus, the story of the two disciples in Mark 16 was probably derived from the Lukan version.

\section{The Location of Emmaus}

The difficulty in determining the exact location of Emmaus is undeniable. One of the reasons is that because there are three textual variants of the distance of Emmaus from Jerusalem (Luke 24:13):

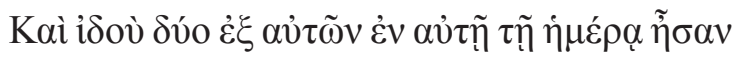

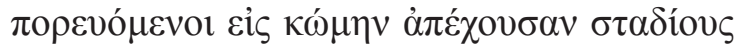

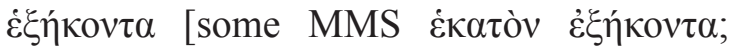

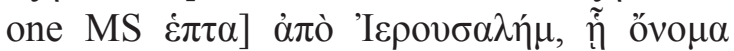

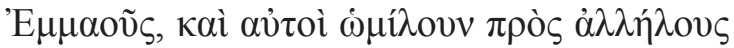

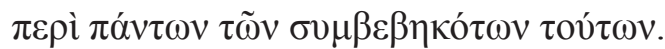

The most reliable reading is sixty stades ( $\sigma \tau \alpha \delta$ íovs $\dot{\varepsilon} \xi \eta \dot{\eta} \kappa o v \tau \alpha$, or about seven miles). This variant is supported by many early and diverse manuscripts such as $\mathfrak{B}^{75}$, A, B, D, $\mathrm{K}^{2}, \mathrm{~L}, \mathrm{~W}, \mathrm{X}, \Delta, \Psi, 063,0124, f^{1}$ and $f^{13}$, along with other Greek miniscule and most of the ancient translations. Furthermore, this distance fits with the Emmaus story that the two disciples are able to travel from and to Jerusalem in one day. ${ }^{14}$

The second textual reading, which is less reliable than the first, is 160 stades ( $\sigma \tau \alpha \delta$ íovs $\dot{\varepsilon} \kappa \alpha \tau o ̀ v \dot{\varepsilon} \xi \eta \dot{\eta} \kappa o v \tau \alpha$, or eighteen miles). Fewer and less diverse manuscripts support this reading. Those manuscripts are $\aleph, \mathrm{K}^{*}, \Theta, \Pi$, $079,1079^{*}$, along with a few ancient versions and some patristic writings such as Eusebius, Jerome, Sozomen). The third and least reliable reading, which is supported by the Old Latin Codex Palatinus $\left(\mathrm{it}^{\mathrm{e}}\right)$, is seven stades (stadia septem), or 0.8 miles. ${ }^{15}$

\footnotetext{
${ }^{13}$ See e.g. Bernard P. Robinson, "The Place of the Emmaus Story in Luke-Acts," New Testament Studies 30.4 (1984): 481-97.

${ }^{14}$ Luke shows that all activities in chapter 24 take place

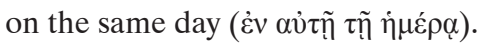

${ }^{15}$ S. Reece, "Seven Stades to Emmaus," New Testament Studies 48.2 (2002): 262-623.
} 
Because of the diversity of textual variants and the fact that the village named Emmaus no longer exists, biblical scholars speculate about the precise location of Emmaus. There are at least five proposals of the location of Emmaus: 1) Ammaus (Latrun), Nicopolis on Greek, located 30 kilometers from Jerusalem; 2) Abu Gosh, about 15 kilometers west of Jerusalem; 3) El Qoubeibeh, 14 kilometers northwest of the holy city; 4) Mozah, a city situated on a hill six kilometers west of Jerusalem, which was called Ammaus by Josephus; and 5) Bir el-Hammam, ten kilometers point to point from Jerusalem and 11 kilometers by road. ${ }^{16}$ Among the five options, according to Bovon, the most probable location is Bir el-Hammam. ${ }^{17}$

\section{The Identity of Cleopas and the Unnamed Disciples}

Biblical scholars have debated about the identity of Cleopas and the other disciples. One certain thing is that the two disciples are not part of the Twelve; therefore, some argue that they belong to the Seventy disciples that were sent by Jesus as written in Luke 10:1-24. For instance, Cyril of Alexandria (c. 376-444) writes,

As two of the disciples walked to a village called Emmaus, they talked about Christ, regarding him as no longer living but mourning him as dead. As they conversed, Jesus drew near and went with them, without being recognized by them, for their eyes were restrained, so that they should not know him. You must know that these disciples belonged to the number of the seventy, and that Cleopas's companion was Simon-not Peter or the one of Cana-but another Simon, of the seventy. ${ }^{18}$

${ }^{16}$ Bovon, Luke 3, 371.

${ }^{17}$ See ibid.

${ }^{18}$ Cyril of Alexandria, Commentary on Luke, Chapter 24 quoted in Arthur A. Just Jr., Luke, Ancient Christian Commentary on Scripture New Testament III (Downers Grove: InterVarsity, 2003), 378.
However, Leifeld argues that they are probably "two of the followers of Jesus who had come to Jerusalem for the Passover. So they had been among the 'disciples' who lauded Jesus on his triumphal entry to the city (19:39) and were now returning home."19 Regarding the identity of Cleopas, he may not be the Clopas in John 19:25, as Bovon states,

A word about Cleopas and his name. The name is an abbreviated form of Cleopatros

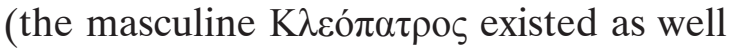

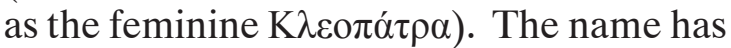
been compared with the Semitic Klopas, but in reality the two names have no relationship. Some have even identified the Cleopas of Luke with Clopas, the husband or the father of one of the three Marys, who, according to John 19:25, stood at the foot of the cross. If, moreover, that Mary was the sister of the Virgin, Cleopas would become Jesus' uncle! ${ }^{20}$

Things are more complicated once we have to identify the unnamed disciple. Various speculation has been proposed such as Simon, but not Peter and the one of Cana, which is the son of Clopas who later became the second bishop of the church at Jerusalem; ${ }^{21}$ Nathaniel, ${ }^{22}$ Luke; ${ }^{23}$ and Cleopas' wife, because the two disciples had dinner together with Jesus at their home. ${ }^{24}$ However, all of the opinions concerning the identity of the two disciples are speculative because the name Cleopas only occurs in this pericope, and the New Testament is silent about the name of the other

${ }^{19}$ Leifeld, "Luke," 1051.

${ }^{20}$ Bovon, Luke 3, 373.

${ }^{21}$ Eusebius, Ecclesiastical History 3.32 quoted in Just Jr., Luke, 379.; Cyril of Alexandria and Origen. See note 18 and Ehrhardt, "Disciples of Emmaus," 182.

${ }^{22}$ See the mention of this opinion in Huffman, "Emmaus among the Resurrection Narratives," 218.

${ }^{23}$ See ibid.

${ }^{24}$ Richard Bauckham, Gospel Women: Studies of the Named Women in the Gospels (Grand Rapids: Eerdmans, 2002), 112; I. Howard Marshall, The Gospel of Luke: A Commentary on the Greek Text, New International Commentary on the New Testament (Grand Rapids: Eerdmans, 1978), 894; Bovon, Luke 3, 370. 
disciple. It is probable that Luke intentionally writes one of the most important passages in his work by including minor and anonymous figures so that his readers may identify themselves with the characters in the Emmaus story. All people of God, regardless of their gender, race, and social class, are invited to partake in this meal with the Lord.

\section{The Ignorance Motif}

Luke as a writer uses irony in several different ways to relate to his readers and to demonstrate the transformation of the disciples and even Jesus-from a stranger to the host-in the Emmaus story. One way that Luke's irony shows is that Cleopas and the other disciple are thinking that Jesus is the only ignorant person in Jerusalem, while the fact is that Jesus is the only one who really knows what was going on at that time. Second, the two disciples cannot see who Jesus is, but they can hear him when Jesus interprets all of the Scriptures. On the other hand, we can "see" Jesus, but we cannot hear what he teaches. ${ }^{25}$ Third, Cleopas calls Jesus the only stranger in Jerusalem ( $\Sigma \dot{v}$

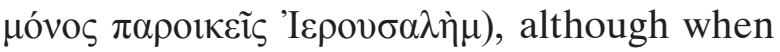
Jesus was entering the city, people welcomed him by laying down their cloaks on the road, spreading cut branches on the road, and singing for him. ${ }^{26}$ Fourth, despite the fact that in this gospel Jesus predicted several times that he would be resurrected on third day (9:22; $13: 32 ; 18: 33)$, the two disciples are not aware that Jesus has been resurrected, even though Cleopas says that "it is now the third day" (

Regarding the ignorance of the two disciples, one can find that again Luke employs the ignorance motif in this passage. For example,

${ }^{25} \mathrm{D}$. Brent Laytham, "Interpretation on the Way to Emmaus: Jesus Performs His Story," Journal of Theological Interpretation 1.1 (2007): 105.

\footnotetext{
${ }^{26}$ James Maxey, "The Road to Emmaus: Changing Expectations A Narrative-Critical Study," Currents in Theology and Mission 32.2 (2005): 104.

${ }^{27}$ Joshua W. Jipp, Divine Visitations and Hospitality to Strangers in Luke-Acts: An Interpretation of the Malta Episode in Acts 28:1-10, Supplement to Novum Testamentum 153 (Leiden: Brill, 2013), 199.
}

in this episode, Luke employs the words

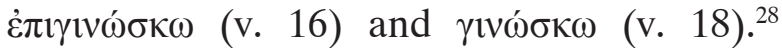
Also, Luke writes this story in such a way that has a "progression from lack of recognition to full recognition." ${ }^{29}$ In this case, the two disciples are contrasted to the women who went to the tomb of Jesus. Luke narrates that while the women know that Jesus was alive (v. 23), Cleopas and the other disciple do not know that Jesus has been resurrected.

In passion-resurrection narrative, however, the two disciples are not the only group of people that Luke depicts as ignorant. Besides them, the Jewish people were also regarded as ignorant because they crucified their Messiah. At the cross, Jesus prayed to his Father, "And Jesus said, 'Father, forgive them, for they know

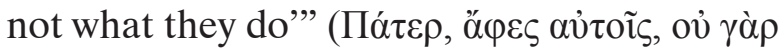

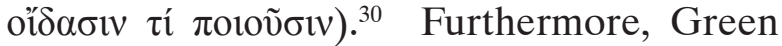
asserts that Herod is also ignorant about Jesus' identity even though when "Herod saw

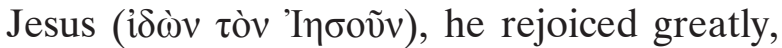
because for a long time he had wanted to

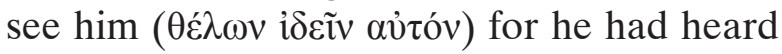
about him and he hoped he might see (i $\delta \varepsilon \tilde{v} v)$ a sign performed by him" (Luke 23:8). ${ }^{31}$ Luke contrasts both Herod and the Jewish people to the centurion who, after he saw what had

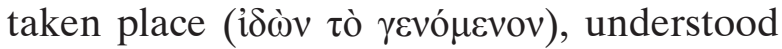
that Jesus was innocent (Luke 23:47). ${ }^{32}$

Besides in the passion-narrative, the ignorance theme is also prominent in the gospel of Luke and the book of Acts. For instance, Jesus' parents are ignorant that the twelveyear-old Jesus is staying at the temple (ovik

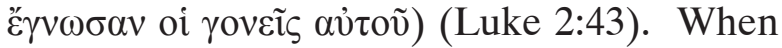
Jesus is weeping over Jerusalem, he says, "Would that you, even you, had known on

${ }^{28}$ Green, The Gospel of Luke, 845.

${ }^{29}$ Ibid., 842.

${ }^{30}$ All English translations are taken from the English Standard Version unless stated otherwise.

${ }^{31}$ Green, The Gospel of Luke., 804.

${ }^{32}$ Joshua W. Jipp, Divine Visitations and Hospitality to Strangers in Luke-Acts: An Interpretation of the Malta Episode in Acts 28:1-10, Supplement to Novum Testamentum 153 (Leiden: Brill, 2013). 


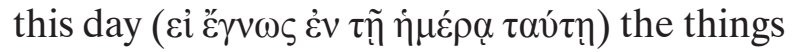
that make for peace! But now they are hidden from your eyes (Luke 19:42). And they will not leave one stone upon another in you, because you did not know the time of your

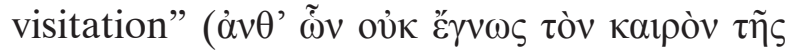
$\dot{\varepsilon} \pi \iota \sigma \kappa \pi \tilde{\eta} \varsigma$ бov) (v. 44). As well, in the book of Acts, Peter, when he is preaching on the day of Pentecost, he says, "Now, fellow Israelites, I know that you acted in ignorance, as did

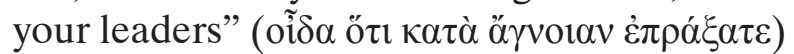
(Acts 3:17). In the same vein, while preaching at a synagogue in Pisidian Antioch, Paul states, "Fellow children of Abraham and you God-fearing Gentiles, it is to us that this message of salvation has been sent. The people of Jerusalem and their rulers did not recog-

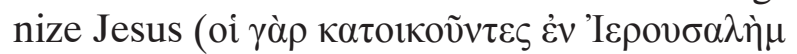

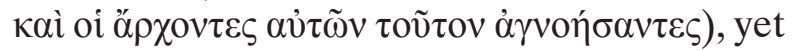
in condemning him they fulfilled the words of the prophets that are read every Sabbath" (Acts 13:26-27).

In the Emmaus account, even though Jesus

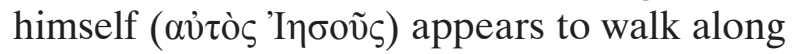
with the two disciples, they do not recognize him (24:15). Luke explains this ignorance with the words "But their eyes were kept from recognizing him" (oi $\delta \dot{\varepsilon}$ ò $\varphi \theta \alpha \lambda \mu$ ò̀

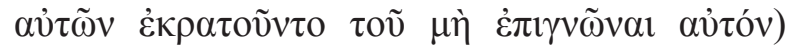
(Luke 24:16). New Testament scholars disagree regarding the meaning of that verse. Some argue that it refers to a supernatural power that keeps the disciples from knowing Jesus. ${ }^{33}$ Similarly, other scholars point out that because

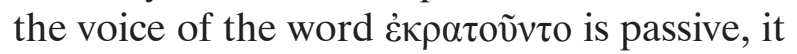
shows that it is a divine passive. ${ }^{34}$ Leifeld also points out that the divine passive should also be applied to the phrase "And their eyes were opened" ( $\alpha \hat{\tau} \tau \tilde{\omega} v \delta \grave{\varepsilon} \delta$ invoí $\theta \eta \eta \sigma \alpha \nu$ oi ỏ $\varphi \theta \alpha \lambda \mu \mathrm{o})$ (v. 31). ${ }^{35}$ The last explanation is more convincing; it seems that their eyes are kept from

\footnotetext{
${ }^{33}$ E.g. Ehrhardt, "The Disciples of Emmaus," 184; Robinson, "The Place of the Emmaus Story in Luke-Acts," 484.

${ }^{34}$ E.g. Robert H. Stein, Luke, New American Commentary 24 (Nashville: Broadman, 1992); Marshall, The Gospel of Luke; Joseph A. Fitzmyer, The Gospel According to Luke, Anchor Bible 28A (Garden City: Doubleday, 2005); Craig A Evans, Luke (Peabody: Hendrickson, 1990).

${ }^{35}$ Leifeld, "Luke," 1504.
}

recognition because of their misunderstanding of God's plan. Regarding this, Tannehill rightly adds,

Rather, there is something inherently difficult in understanding God's way of working through the death of Jesus. God holds human eyes in the sense that God's ways necessarily appear meaningless to humans who understand events in terms of their own purposes and ways of achieving them. A new vision of how God work salvation in the world must be granted to the disciples before a crucified and risen messiah can be meaningful for them. ${ }^{36}$

This explanation is more probable because Jesus rebukes their ignorance regarding God's

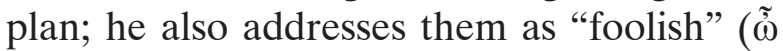

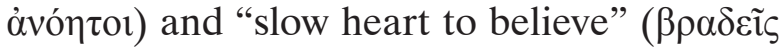

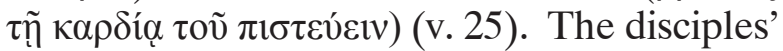
inability to recognize the resurrected Jesus is closely related to their inability to understand that the Messiah has to die and be resurrected. Regarding this, I agree with what Laytham states,

Because Jesus "was a prophet mighty in deed and word" (24:19), they had hoped that in him God's promise was being fulfilled. But they could not imagine Jesus' crucifixion as a faithful performance of his prophetic ministry and of Israel's messianic hopes. So their problem was larger than their inability to recognize this stranger as their risen Lord. It was also their inability to recognize Jesus' passion as a faithful performance of "Moses and all the prophets" (24:27). In the end, Jesus' performance on the cross seemed to them a stranger to Scripture rather than its faithful embodiment. ${ }^{37}$

Furthermore, this is not the disciples' first instance of ignorance. When Jesus is predicting that Jesus has to suffer and die, his disciples cannot understand and "it was

\footnotetext{
${ }^{36}$ Tannehill, The Narrative Unity of Luke - Acts, 282.
}

${ }^{37}$ D. Brent Laytham, "Interpretation on the Way to Emmaus: Jesus Performs His Story," Journal of Theological Interpretation 1.1 (2007): 101-15. 103 (emphasis mine). 
concealed from them so that they might not

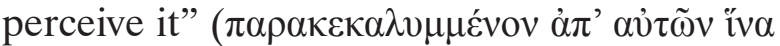

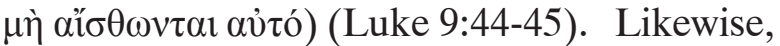
in Luke 18:31-34, when Jesus tells his disciples that he will be delivered to the Gentiles, crucified, and resurrected on the third day, "this saying was hidden from them, and they

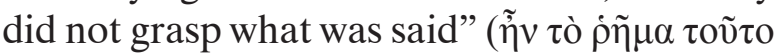

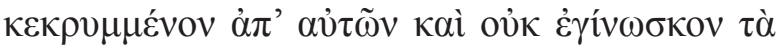
$\lambda \varepsilon \gamma \delta \dot{\mu \varepsilon v \alpha)}\left(\right.$ v. 34). ${ }^{38}$

The ignorance motif in Luke and Acts is closely related to the very same motif of ignorance in the book of Isaiah. In Isaiah, the people of Israel are frequently depicted by use of the metaphors of blindness and deafness. For example, Isaiah writes, "Make the heart of this people dull, and their ears heavy, and blind their eyes; lest they see with their eyes, and hear with their ears, and understand with their hearts, and turn and be healed" (Isa 6:10; cf. 29:10). However, in the second part of the book of Isaiah, the prophet proclaims the comfort of Yahweh to his people: the blind will see, and the deaf will hear. For instance, this consolation is written in Isaiah 42:6-7, "I am the LORD; I have called you in righteousness; I will take you by the hand and keep you; I will give you as a covenant for the people, a light for the nations, to open the eyes that are blind, to bring out the prisoners from the dungeon, from the prison those who sit in darkness" (cf. 42:16, 18). About this metaphor, David W. Pao rightly asserts, "In Isaiah, the indictment of Isa. 6:9-10 is not the final statement of the people of God. The coming of the salvation of God in Isaiah 40-55 represents a situation in which the people of God will regain the chance to be the recipients of the salvation of God." ${ }^{39}$ In the Emmaus account, one also can see that the disciples undergo a transition from the blind state to the seeing state, from ignorance to understanding. Luke 24:31 says, "And their eyes were opened, and

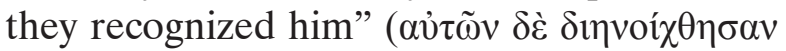

\footnotetext{
${ }^{38}$ Jipp, Divine Visitations and Hospitality to Strangers in Luke-Acts, 198.

${ }^{39}$ David W. Pao, Acts and the Isaianic New Exodus, Wissenschafitliche Untersuchungen zum Neuen Testament 2. Reihe 130 (Tübingen: Mohr Siebeck, 2000), 106.
}

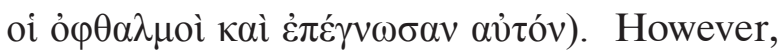
how do the disciples come to recognize Jesus? What makes them understand that the Messiah has to suffer, die, and be resurrected? I will address this question in a following section of this paper.

\section{Jesus: The Rejected Prophet}

Cleopas tells to Jesus things that happened in Jerusalem related to "Jesus of Nazareth"

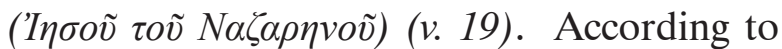
Green, in this passage, the phrase "Jesus of Nazareth" refers to the beginning of Jesus's ministry when he proclaims that he has been anointed by the Spirit to perform miracles and to teach powerfully, as stated by Cleopas that Jesus is a prophet powerful in deed and word. ${ }^{40}$ However, it seems to me beyond that, Luke also deliberately employs that title to emphasize that Jesus is the rejected prophet since, in his hometown, Nazareth, Jesus was rejected (Luke 4:24-30). ${ }^{41}$ This understanding that Jesus, as a prophet, has to be rejected is incomprehensible to his disciples. As Green observes,

What is lacking in their interpretation of Jesus' significance, however, is the understanding that, as God's prophet, Jesus must fulfill the destiny of the prophets: rejection, suffering, and death. They thus misunderstand the prophetic pattern in the Scriptures that Jesus fulfills. What is more, even though they regard Jesus as a prophet, they have failed to take with appropriate seriousness his prophecies regarding his own suffering, death, and resurrection. ${ }^{42}$

As mentioned above, Luke in the book of Acts also addresses inability of the Jewish people to understand that the Messiah has to suffer (3:17). At the Pentecost, Peter preaches to his

\footnotetext{
${ }^{40}$ Green, The Gospel of Luke, 846.

${ }^{41}$ According to Pao, Luke deliberately put the Nazareth episode in the beginning of his gospel, while the arrangement of the gospel of Mark seems to be proper chronologically. The reason of his rearrangement is that Luke wants to highlight the rejection by the people of God. See Pao, Acts and the Isaianic New Exodus, 78-80.

${ }^{42}$ Green, The Gospel of Luke., 846.
} 
fellow Jews that the suffering and the crucifixion of the Messiah is not a contradiction of Jesus' mission but the fulfilment of the plan of God (e.g. Acts 2:22, "This man was handed over to you by God's deliberate plan and foreknowledge; and you, with the help of wicked men, put him to death by nailing him to the cross. But God raised him from the dead, freeing him from the agony of death, because it was impossible for death to keep its hold on him;" cf. 4:10; 26:22). ${ }^{43}$ Moreover, the notion of the suffering, death, and resurrection of the Messiah is very significant in the resurrection appearance accounts in Luke (ch. 24), since it also occurs in the empty tomb (24:6-7), at Emmaus (24:18-27), and during the appearance to the Eleven episode (24:44-46) ${ }^{44}$ The recurrence is to highlight that even though Jesus has predicted his suffering, death, and resurrection several times, his disciples are still unable to comprehend it.

To Jesus, Cleopas says Jesus is a prophet mighty in deed and word before God and his people. He also says they have hope that Jesus will redeem Israel. To this point, what the two disciples understand of Jesus is accurate. ${ }^{45}$ The understanding of Jesus as a prophet is prevalent in Luke and Acts. ${ }^{46}$ For example, in Luke 4:14, Jesus refers to himself as a rejected prophet by saying, "Truly, I say to you, no prophet is acceptable in his hometown." To some Pharisees, Jesus says he is a part of prophets who have been killed by the people of Jerusalem: "Nevertheless, I must go on my way today and tomorrow and the day following, for it cannot be that a prophet should perish away from Jerusalem. O Jerusalem, Jerusalem, the city that kills the prophets and stones those who are sent to it! How

\footnotetext{
${ }^{43}$ Ibid., 834.

${ }^{44}$ Tannehill, The Narrative Unity of Luke - Acts, 277.

${ }^{45}$ Ibid., 280.
}

${ }^{46}$ According to J. Severino Croatto, in the third gospel, "the prophetic character of Jesus is (a) the epistemological center (at the literary and semantic level) and (b) the essential kerygma (at the communicational level)." See J. Severino Croatto, "Jesus, Prophet like Elijah, and Prophet-Teacher like Moses in Luke-Acts," Journal of Biblical Literature 124.3 (2005): 452. often would I have gathered your children together as a hen gathers her brood under her wings, and you were not willing!" (Luke 13:33-34). In Acts 3:22-24, Peter preaches to the Jewish people, saying Jesus is the prophet who has been prophesied by Moses and all the prophets. In his address, Stephan also makes reference to Jesus as a prophet prophesied by Moses (Acts. 7:37).

As mentioned above, Cleopas also says Jesus is "a prophet powerful in deeds and word." Luke addresses this notion when he narrates the beginning of Jesus' ministry: "And Jesus returned in the power of the Spirit to Galilee, and a report about him went out through all the surrounding country. And he taught in their synagogues, being glorified by all" (4:1415). Also, Tannehill asserts that the phrase "powerful in deeds and word" is related to the beginning of the book of Acts, which says, "In the first book, O Theophilus, I have dealt with all that Jesus began to do and teach (Acts 1:1; cf. 2:22). ${ }^{47}$

The next phrase Cleopas uses is "before God and all the people" (Luke 24:19). Some argue that that is an allusion to Deuteronomy 34:1012: "And there has not arisen a prophet since in Israel like Moses, whom the Lord knew face to face, none like him for all the signs and the wonders that the Lord sent him to do in the land of Egypt, to Pharaoh and to all his servants and to all his land, and for all the mighty power and all the great deeds of terror that Moses did in the sight of all Israel." 48 This phrase also appears in Stephen's speech to the Jewish leaders when Stephen refers to Moses: "And Moses was instructed in all the wisdom of the Egyptians, and he was mighty in his words and deeds" (Acts 7:22). The importance of identification of Jesus as Moses is not only the description that Jesus is a prophet powerful in deeds and word but also a reference to Israel's rejection of him. In the same speech, Stephen says concerning Moses, "But

\footnotetext{
${ }^{47}$ Tannehill, The Narrative Unity of Luke - Acts, vol. 1: The Gospel according to Luke, 280.

${ }^{48}$ E.g. Robinson, "The Place of the Emmaus Story in Luke-Acts," 482; Green, The Gospel of Luke, 846.
} 
our ancestors refused to obey him. Instead, they rejected him and in their hearts turned back to Egypt" (Acts 7:39). Moreover, Stephen rebukes the Jewish leaders because they belong to the people of God who have persecuted all prophets and even killed Jesus:

You stiff-necked people! Your hearts and ears are still uncircumcised. You are just like your ancestors: You always resist the Holy Spirit! Was there ever a prophet your ancestors did not persecute? They even killed those who predicted the coming of the Righteous One. And now you have betrayed and murdered him-you who have received the law that was given through angels but have not obeyed it (Acts 7:51-53).

Moreover, Cleopas also says to Jesus that they have hoped that Jesus is the one to

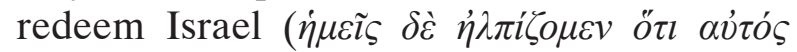

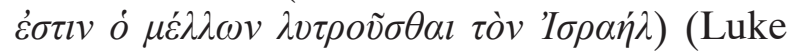
24:21). From the beginning of his gospel, Luke emphasizes the redemption of his people. In his song, Zechariah says, "Blessed be the Lord God of Israel, for he has visited

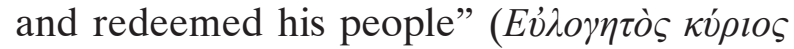

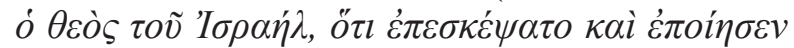
$\lambda v i \tau \omega \sigma l v \tau \tilde{\varphi} \lambda \alpha \tilde{\omega} \alpha \dot{\tau} \tau o \tilde{v})$ (Luke 1:68). ${ }^{49}$ The hope of Israel for the redemption from God is also found in episode of the prophetess Anna. Luke narrates, "And coming up at that very hour she began to give thanks to God and to speak of him to all who were waiting

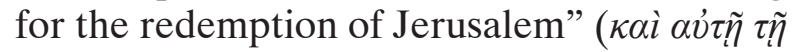

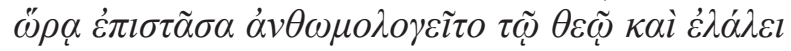

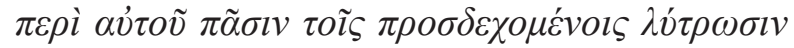

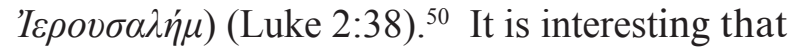
the word $\lambda v i \tau \omega \sigma i \varsigma$ (redemption) only occurs three times in the New Testament; two of those can be found in the third gospel (1:68; 2:38), and the other is in Hebrews 9:12. This occurrence means that the theme of redemption is important in the gospel of Luke.

In his sayings to Cleopas and the unnamed disciple, Jesus also discusses Moses. $\mathrm{He}$

\footnotetext{
${ }^{49}$ Also Leifeld, "Luke," 1052.

${ }^{50}$ Also ibid.
}

says, "And beginning with Moses and all the Prophets, he interpreted to them in all the Scriptures the things concerning himself (kai $\dot{\alpha} \rho \xi \dot{\alpha} \mu \varepsilon v o \varsigma \alpha \dot{\alpha} \pi \dot{o} M \omega \ddot{v} \sigma \varepsilon \dot{\varepsilon} \omega \varsigma \kappa \alpha \grave{\alpha} \dot{\alpha} \pi \dot{o} \pi \dot{\alpha} v \tau \omega v \tau \tilde{\omega} v$

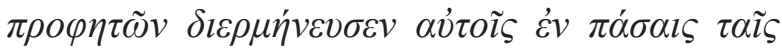

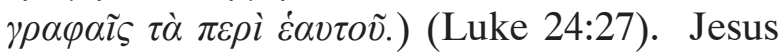
teaches his disciples that his suffering, death, and resurrection have been prophesied in the Old Testament. In this case, a lengthy quotation from Augustine is worth citing:

So he began to expound the Scriptures to them to help them recognize Christ precisely in the point on which they had forsaken Christ. The reason, you see, that they had despaired of Christ was that they had seen him dead. He, however, opened the Scriptures to them, so that they would realize that if he hadn't died, he couldn't be the Christ. He taught them from the following Scriptures, he taught them from the prophets what he himself had told them: that is was necessary that the Christ should suffer these things and enter into his glory. They listened, they were filled with joy, they breathed again, and, as they said themselves, their hearts burned with them. And still they didn't recognize the presence of the light. ${ }^{51}$

By interpreting ( $\delta \varepsilon \rho \mu \eta \dot{v \varepsilon v \sigma \varepsilon v) ~ f o r ~ t h e m ~ a l l ~}$ the Scriptures from Moses and all the prophets, Jesus not only teaches the disciples that his suffering, crucifixion, and resurrection confirm the God's salvation plan, but he also identifies himself with the prophets that have been rejected by the Israelites. Regarding this notion, Green rightly points out,

When the reference to "Moses and all the prophets" in 24:27 "Then beginning with Moses and all the prophets, he interpreted to them the things about himself in all the scriptures") is factored in, the logic of Jesus' exposition is perhaps based on a correlation of the destiny of the prophets who were rejected, who suffered, and who were often killed with his fate as the Messiah, asserting that the Scriptures "presage

${ }^{51}$ Augustine, Sermon 236.2 quoted in Just Jr., Luke, 380. 
the eschatological king who would suffer before entering his glory. ${ }^{52}$

\section{And Their Eyes Were Opened, and They Recognized Him"}

The report from the women about the empty tomb and the angelic vision do not convince the disciples to accept the Messiahship of Jesus. Neither can the appearance of Jesus make the two disciples understand God's plan of salvation through the death and the resurrection of the Messiah. On this occasion, different from what Jesus does to Thomas, the catalyst of belief is not the appearance of Jesus but his action. ${ }^{53}$ When Jesus and the two disciples are approaching to the village of Emmaus, it is nearly evening. Jesus pretends

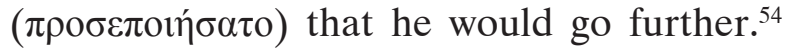
It is interesting that Jesus needs to pretend twice to open the "blindness" of the two disciples. First, he pretends that he is a stranger and ignorant of the situation in Jerusalem. Second, he pretends that he would continue his journey. Knowing that Jesus would travel further, they compel ( $\pi \alpha \rho \varepsilon \beta 1 \alpha$ ó $\sigma \alpha \nu \tau)$ Jesus to stay with them (Luke 24:29). It is like when Lydia urges Paul, Silas, and Luke (because of the employment of "we" in this story) to come to her house and stay (Acts 16:15). ${ }^{55}$

${ }^{52}$ Green, The Gospel of Luke, 257 cf. David W. Pao and Eckhard J. Schnabel, "Luke," in Commentary on the New Testament Use of the Old Testament, ed. G.K. Beale and D.A. Carson (Grand Rapids/Nottingham: Baker Academic, 2007), 400; Tannehill, The Narrative Unity of Luke - Acts, 286. 110 .

${ }^{53}$ Laytham, "Interpretation on the Way to Emmaus,"

${ }^{54}$ Interestingly, the word $\pi \rho \circ \sigma \pi$ oเé $\omega$ is hapax legomena in the New Testament. Another use in the LXX with the same meaning is in 1 Samuel 21:14, "Then Achish said to his servants, 'Behold, you see the man behaving ( me?"”

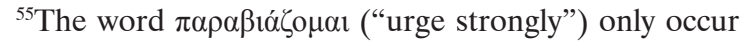
twice in the New Testament and both occurrences are in the Lukan writings (Luke 24:29 and Acts 16:15).
At the disciples' house, ${ }^{56}$ Jesus opens their eyes so that they can recognize him. An interesting fact is that their eyes were not opened yet when they were listening to Jesus interpreting all of the Scriptures. Then, what has made them recognize Jesus? Jipp and Denaux have proposed that the catalyst is their hospitality to Jesus as a divine visitor. It was protocol that a stranger had to reveal his identity to the host before being accepted as a guest. Jipp has pointed out, "Given the symbolic and literary significance of hospitality to strangers within the Lukan writings, and given the fact that hospitality is the single proper response to all travelers and especially journeying deities in theoxenies, the reader anticipates the disclosure of Jesus' identity to the disciples." 57 Even though that argument is quite fascinating, it seems that what makes the eyes of the disciples open is more than their hospitality. There are two major objections to the hospitality argument. First, if we read the passage closely, we will get an impression that the disciples do not immediately recognize Jesus after they invite Jesus to stay at their home. There appears to be a time gap between verse 29, "So he went in to stay with them," and verse 30-31, "When he was at table with them, he took the bread and blessed and broke it and gave it to them. And their eyes were opened, and they recognized him." The disciples do not immediately identify Jesus after they give him hospitality. Second, in the Emmaus account, the phrase kai

\footnotetext{
${ }^{56}$ It is uncertain whether the location is Cleopas' house or the other disciples'. If the opinion that both disciples are Cleopas and his wife are correct, then Jesus took a bread at their house.

${ }^{57}$ Jipp, Divine Visitations and Hospitality to Strangers in Luke-Acts, 200; Denaux, "A Stranger in the City," 260. In his article, Denaux explains that the portrayal of Jesus as a stranger is prominent. Luke narrates that Jesus was born away from his hometown. When he was twelve years old, he is a stranger in his parents' house since his home is the Temple. In his ministry, Jesus are wandering and has nowhere to lay his head (Luke 9:58). Even the people of Nazareth, his hometown, rejected him. This argument is quite compelling. However, the portrayal of Jesus as a stranger does not fit with the Lukan paradigm of Jesus in Luke-Acts, such as Jesus as the rejected prophet, the suffering and resurrected Messiah.
} 


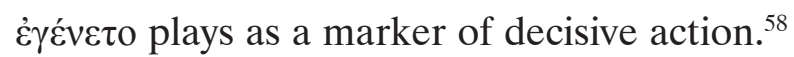
The first crucial moment is in verse 15, "While

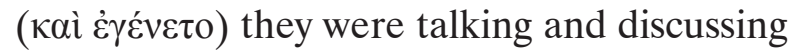
together, Jesus himself drew near and went with them." The second decisive moment is in

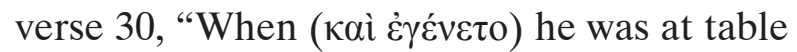
with them, he took the bread and blessed and broke it and gave it to them. And their eyes were opened, and they recognized him." To conclude, the precise moment that causes the disciples to recognize Jesus is when he takes the bread, blesses it, breaks it, and gives it to them because the recognition does not happen before the meal.

As to the specific part of the meal that opens the disciples' eyes, some argue that the fourfold action of Jesus, "he took ( $\lambda \alpha \beta \omega v)$ the

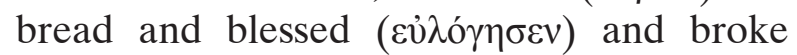

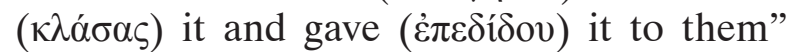
makes the disciples recognize Jesus (v. 30). ${ }^{59}$ In other words, "The formula 'he took the bread, blessed it, and when he had bro-

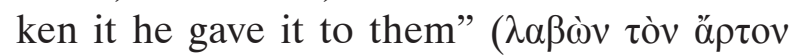

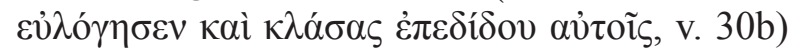
recalls what Jesus did in the last supper: "and after he had taken a loaf and had given thanks,

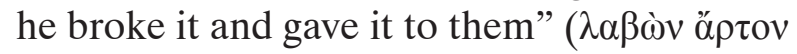

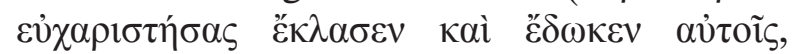
22:19a). ${ }^{60}$ Even though this argument looks convincing, it is not without problems. If we compare those verses carefully, we will find that the two phrases are not perfectly identical. The second action of Jesus recorded in Luke 24:30 is that he "blessed" ( $\varepsilon \dot{\lambda} \lambda \mathrm{o} \gamma \varepsilon \dot{\varepsilon} \omega$ ) the bread," while what Jesus does in the last supper after he takes the bread is "give thanks"

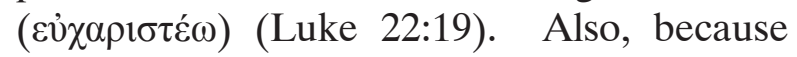
Cleopas and the other disciple do not participate in the last supper, they are unlikely to connote Jesus' action at their home with the last supper. ${ }^{61}$

${ }^{58}$ Bovon, Luke 3, 372; Laytham, "Interpretation on the Way to Emmaus," 109.

${ }^{59}$ E.g. Laytham, "Interpretation on the Way to Emmaus," 111.

${ }^{60}$ Bovon, Luke 3.

${ }^{61}$ Robinson, "The Place of the Emmaus Story in LukeActs," 487.
Consequently, some biblical scholars have shown that the Emmaus meal is more related to the feeding of the five thousand (Luke 9:12-17) than the last supper. Several reasons support this argument. First, as mentioned

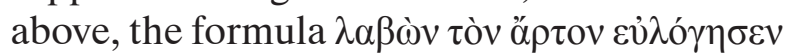

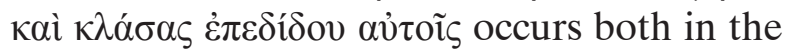
Emmaus meal (24:30) and the feeding miracle, "And taking $(\lambda \alpha \beta \omega) v)$ the five loaves and the two fish, he looked up to heaven and

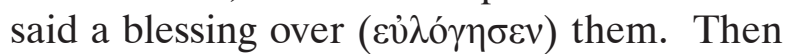

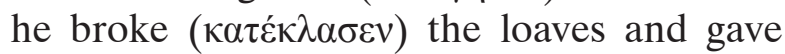
( $\dot{\delta} \delta$ íov) them to the disciples to set before the crowd" (9:16). ${ }^{62}$ Second, instances after the Emmaus meal and the feeding of five thousand have revelatory significances that lead to the understanding of the Messiahship of Jesus. ${ }^{63}$ After the story of the feeding of the five thousand, Luke narrates the confession of Peter. After other disciples mention the misconception of the crowds and probably that of the disciples toward Jesus, Peter confesses, that Jesus is "The Christ of God" (9:18). Similarly, after having the meal, the two disciples in Emmaus recognize that Jesus is the Messiah. Third, Luke puts the temporal signal both in the Emmaus episode and the story of the five thousand. Luke 24:29 says, "for it is toward evening and the day is now far spent" (ö $\tau 1$

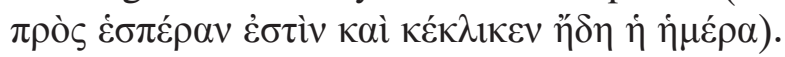
While in the story of the feeding miracle, Luke narrates, "Now the day began to wear

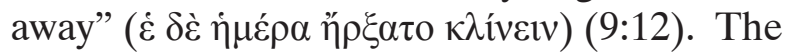
word $\kappa \lambda i v \omega$ (decline) is used in both stories. Fourth, both in Luke 24:13-35 and Luke 9:10-

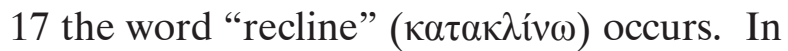
the Emmaus story, Luke narrates, "When he

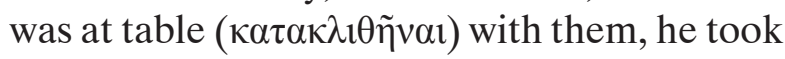
the bread and blessed and broke it and gave it to them." Whereas in the feeding of the five thousand story, it says, "For there were about five thousand men. And he said to his dis-

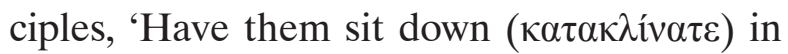
groups of about fifty each.' And they did so,

\footnotetext{
${ }^{62}$ Green, The Gospel of Luke, 849; Tannehill, The Narrative Unity of Luke - Acts, 289.

${ }^{63}$ Green, The Gospel of Luke, 843; James Maxey, "The Road to Emmaus: Changing Expectations A Narrative-Critical Study," Currents in Theology and Mission 32.2 (2005): 122.
} 


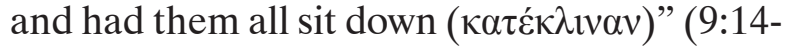
15). On the other hand, in the last supper episode, Luke uses the word $\alpha v \alpha \pi i \pi \tau \omega$ (22:14) instead of $\kappa \alpha \tau \alpha \kappa \lambda i v \omega$ to express the identical idea of "recline," On other word, the impetus of recognition of the two disciples is that their rememberance of the event of the feeding of the thousand, when Jesus acts as the host for his disciples and the crowds. Even though the Emmaus meal is more reminiscent of the feeding of the thousands, both stories should be understood in light of Eucharistic meal since the last supper was a part of the early church liturgy. ${ }^{64}$ In the gospel of Luke, Jesus is described as one who is engaged in many table-fellowships, but among those meals, Jesus acts as the host only three times: in the feeding of the five thousand, the last supper, and the Emmaus meal. Compared to the two other meals, the Emmaus meal is exceptional since it involves the progression of Jesus as the stranger-become-guest-and-then-the-host. The transformation also happens among the disciples who were ignorant and then received opened hearts and eyes, who were hopeless and sobered and then changed to be on fire and joyful. ${ }^{65}$ I argue that the catalyst of eyes opening and their recognition is not the fourfold action of the meal, the elements of the meal, or the prayer of Jesus. The catalyst of the disciples' recognition of Jesus is the act of Jesus as the host for them.

\section{Jesus Is The Host of the Coming Messianic Banquet}

The notion of Jesus as the host should be traced back to the Old Testament. We can find three points that related to the idea of Yahweh as the host for Israel and the nations. First of all, Yahweh as the host of Israel is

${ }^{64}$ Robinson, "The Place of the Emmaus Story in LukeActs," 487.

${ }^{65}$ On what/who makes the disciples' hearts burn, the church fathers were not unanimous. Several views regarding this: (1) the Holy Spirit (Origen in Homilies on Leviticus 9.9.7); (2) the flames of the divine Scripture (Ambrose in Isaac, or the Soul 8.77); (3) the Lamb of the tribe of Judah (Origen in Homilies on Exodus 12.4); (4) The fire of charity (Augustine in Sermon 234.3). See Just Jr., Luke, 382-383. related to the covenant-making ceremony between Yahweh and Israel. After the Israelites made a covenant with Yahweh by pledging that they would commit to obey all the words of God, Moses wrote down everything that the Lord had said. Then on the following day, Moses built an altar with twelve stone pillars representing the twelve tribes of Israel. After leading a ceremony that included the sprinkling of blood, Moses read the words of the Lord again, and the Israelites responded by saying that they would obey everything the Lord had said. Afterward, the Lord invited Moses, Aaron, Nadab, Abihu, and seventy elders to go up the mountain. At the top of the mountain, "they beheld God, and ate and drank" (Ex 24:11). Brevard S. Childs points out that the meal provided by the Lord is "a culmination of the rite in 3-8, and not as a rival ceremony." ${ }^{66}$ E.W. Nicholson also points out that "the cultic activity of eating and drinking appears as a means of worshipping and rejoicing in God's presence," which is evident in some passages, such as Exodus 8:12; Deuteronomy $12: 7,14: 26$, and 27:7; and 1 Chronicles 29:22. ${ }^{67}$ If this interpretation is correct, Yahweh intended his banquet to build a relationship between Yahweh and his people who have made a covenant that they will hear and obey his words (Ex. 24:3-8).

Second, Yahweh as the host of Israel is a symbol of God's mercy and guidance toward his covenantal people. In Deuteronomy $26: 5$, Israel was portrayed as the "wandering Aramean" sojourning in the wilderness. Initially, the people of Israel were captured as slaves in the Egyptian land. Then they cried to God asking for his liberation; God redeemed them and guided them to the Promised Land. While the people were strangers in the wilderness, God provided them with manna and water (Ex. 6-7), and at last, they lived on the land of God, enjoying his presence in the house of the Lord. John Koenig describes

\footnotetext{
${ }^{66}$ Brevard S. Childs, Exodus: A Commentary, Old Testament Library (Louisville: Westminster John Knox, 1974), 502 .

${ }^{67}$ Ernest W. Nicholson, "Interpretation of Exodus 24:911," Vetus Testamentum 24.1 (1974): 93-94.
} 
the way the Israelites would have imagined themselves feasting in God's kingdom:

Precisely as inhabitants of the land, they pictured themselves being led into green pastures and feted at the table of the divine king in the presence of their enemies. The "house of the Lord" in which they hoped to dwell forever was essentially God's perpetual hosting (Psalm 23; see also Psalm 104 in which God is portrayed as feeding and sustaining the entire creation day by day). When Israel's prophets looked forward to an era of perfect righteousness and shalom, it was no accident that they envisioned God entertaining the people at an endless feast (Amos 9:13-15; Joel 3:18; Isa $25: 6-8) .{ }^{68}$

Third, the eschatological banquet has broader theological and spiritual meanings and a broader scope of the people who partake in it. Isaiah 25:6-9 says,

On this mountain the Lord of hosts will make for all peoples a feast of rich food, a feast of well-aged wine, of rich food full of marrow, of aged wine well refined. And he will swallow up on this mountain the covering that is cast over all peoples, the veil that is spread over all nations. He will swallow up death forever; and the Lord God will wipe away tears from all faces, and the reproach of his people he will take away from all the earth, for the Lord has spoken. It will be said on that day, "Behold, this is our God; we have waited for him, that he might save us. This is the Lord; we have waited for him; let us be glad and rejoice in his salvation.

According to Brant Pitre, Isaiah's eschatological banquet features several elements. ${ }^{69}$ First, it has the dimension of the cessation of the death and the resurrection of the dead. $\mathrm{He}$ infers that notion from the phrase, "He will swallow up death forever" and "will wipe

\footnotetext{
${ }^{68}$ John Koenig, "Hospitality," ABD 3:300.

${ }^{69}$ Brant Pitre, "Jesus, the Messianic Wedding Banquet, and the Restoration of Israel," Letter \& Spirit 8 (2012): 135-
} 136. away tears from all faces." Second, it contains the forgiveness of sins, because God will take away "the reproach of his people" and will give them salvation. Third, it will be a liturgical banquet. The metaphor of "rich food" and "well-aged wine" are technical terminologies for sacrificial offerings of the Temple cult,s as Deuteronomy 32:37-38 says, "Then he will say, 'Where are their gods, the rock in which they took refuge, who ate the fat of their sacrifices and drank the wine of their drink offering? Let them rise up and help you; let them be your protection!" This means that the eschatological banquet will take place at the temple. Fourth, the messianic banquet will include all nations, as the Lord will make the banquet for "all peoples."70

The motif of the Lord as the host and of table-fellowship continues in the New Testament. In the gospels, especially in the third gospel, Jesus proclaims the kingdom of God in the metaphors of food and drink. For example, Luke is the only gospel that has the story of the rich man and Lazarus (Luke 16:19), and the series of parables of the lost that end with the feast (Luke 15). Furthermore, in Luke 14:16-24, Jesus narrates a story of the kingdom of God that is portrayed as a great banquet. Moreover, Luke 13:28-29 says, "In that place there will be weeping and gnashing of teeth, when you see Abraham and Isaac and Jacob and all the prophets in the kingdom of God but you yourselves cast out. And people will come from east and west, and from north and south, and recline at table in the kingdom of God." Concerning the last sentence in that passage, Pitre points out that it alludes to two passages in the Old Testament, Isaiah 43:5-9 and Zechariah 8:7-8, 20-23. He concludes that,

Therefore, when placed against the backdrop of Jewish Scripture, Jesus' description of the gathering of the multitude to dine in "the Kingdom" is a very biblical vision of the eschatological restoration of Israel and the Gentiles. Neither a wholesale rejection of Israel nor an exclusively Israelite

\footnotetext{
${ }^{70}$ Koenig, "Hospitality," 3:300.
} 
vision of salvation is in view. Those who are excluded from the banquet are neither the Jewish people as a whole nor the Gentile nations as a whole, but instead those who reject Jesus' proclamation of the Kingdom. ${ }^{71}$

In other words, that sentence elucidates the inclusion of the Gentiles to the people of God. Jesus not only uses the banquet as a metaphor for the kingdom of God, but he also sits together with his people to eat meals. In the third gospel, one can easily find the table-fellowship motif where Jesus is eating together with all groups of people. He has a meal together with Pharisees and the Scribes (7:3650 ; 11:37-52), his disciples $(22: 14-38 ; 24: 28$ $32 ; 36-43)$, tax collectors and sinners (5:27-32; $19: 1-10)$, women (10:25-37), and the crowds (9:10-17). By doing so, Jesus demonstrates what he proclaims that all people including the poor, cripple, blind and lame are invited to the messianic banquet. In accord to this teaching, Pao argues that the table fellowship motif in the third gospel has three corelated themes. ${ }^{72}$ First, it has the theme of inclusion of the outcasts; second, it emphasizes the eschatological reversal that is the inclusion of the those who are outside of the covenant; third, it features the formation of the eschatological community.

Furthermore, Jesus not only proclaims the messianic banquet, but he also performs the messianic banquet, especially when he acts as the host for his people. As mentioned above, the three meals where Jesus plays a role as the host are the feeding of the five thousand (9:10-17), the last supper (24:14-38), and the Emmaus meal (24:28-32). By acting as the host, Jesus proclaims that the kingdom of God is already coming. ${ }^{73} \mathrm{He}$ also emphasizes that he is the King and the Provider of the people

\footnotetext{
${ }^{71}$ Pitre, "Jesus, the Messianic Wedding Banquet, and the Restoration of Israel," 143.

${ }^{72}$ David W. Pao, "Waiters or Preachers: Acts 6:1-7 and the Lukan Table Fellowship Motif," Journal of Biblical Literature 130.1 (2011): 133-135.
}

${ }^{73}$ Robinson, "The Place of the Emmaus Story in LukeActs," 486. of God, just as Yahweh provided the Israelites with manna in the wilderness and ruled over his kingdom. Therefore, the believers have to trust Jesus. In addition, Jesus also emphasizes the "already-but-not-yet" state of the kingdom of God because we are still waiting for the ultimate messianic banquet to come, as he says, "for I tell you I will not eat it until it is fulfilled in the kingdom of God" in the last supper (Luke 22:18).

As I have mentioned above, the Emmaus episode plays an essential role as a bridge between the gospel of Luke and the book of Acts because it contains central themes that are prevalent in both Luke and Acts. One of the main themes is the table-fellowship. As in the Emmaus meal, Jesus performs as the host as an anticipation of the coming messianic banquet; in Acts, the practice of breaking bread should also be understood to have the same meaning. Green is right to note,

The "breaking of the bread" refers to the meal itself, and thus provides a bridge from table fellowship during Jesus' ministry to the celebrative meals characteristic of the early church in Acts (e.g., Acts $2: 46)$. Given the background in Jesus' own table practices for occasions of "breaking bread" in Acts, we might anticipate that these meals would signify the coming near of salvation, and this is certainly the case. ${ }^{74}$

The breaking of bread in the book of Acts has three meanings for the early church. First, by breaking bread, the early Christians are embodying the death and the resurrection of Jesus in their daily life. As I have argued above, in the Emmaus account, the two disciples were ignorant that the Messiah had to suffer, die, and be resurrected. After they participated in the meal with God, their eyes were opened so that they could recognize Jesus and understand God's salvation plan through the death and the resurrection of Jesus. Because of the emphasis on the discourses of the rejected prophet, the death, and the resurrection of Christ in the book of Acts, one can assume

\footnotetext{
${ }^{74}$ Green, The Gospel of Luke, 851.
} 
that the early believers have understood that those things are in line with God's salvation plan. For example, in Acts 27:35, Paul acts as the host for the sailors and the prisoners in the shipwreck episode, "And when he had

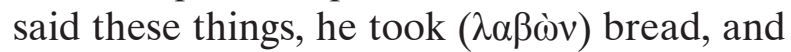

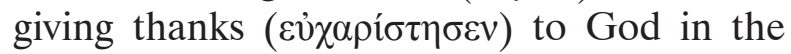
presence of all he broke ( $\kappa \lambda \dot{\sigma} \sigma \alpha \varsigma)$ it and began to eat." In this episode, Paul's action is reminiscent of what Jesus did in the last supper. However, I do not think that Paul is leading the Eucharist because the partakers are not believers. It seems to me that Paul is reenacting the action of Jesus as the rejected prophet who is about to suffer and die on the cross. Paul is embodying the death of the Messiah because he is aware that his own suffering and death are about to take place.

Second, breaking bread is the manifestation of the kingdom of God that has come when all people of God, regardless of their ethnicities, genders, and social statuses, have fellowship with one another and with the risen Messiah. The meal motif in the book of Acts is the fulfillment of what Jesus teaches in Luke 13:29: "And people will come from east and west, and from north and south, and recline at table in the kingdom of God." In the early church, all people of God are invited to the fellowship with other believers who are the Jews, the outcast, and the Gentiles. Besides that, they also have a fellowship with the risen Lord. Third, the breaking of bread is the anticipation of the coming messianic banquet where we will have the ultimate fellowship with all believers and God in the new heaven and the new earth.

\section{Conclusion}

Before partaking the meal hosted by Jesus, Cleopas and the other disciple were ignorant of God's plan that the Messiah should suffer, die, and be resurrected. By acting as the host for the disciples, Jesus made their eyes open so that they may recognize him and comprehend the salvation plan of God. By being the host, Jesus is also showing that he is the Lord who has chosen the people of Israel and made a covenant with them. He also teaches the disciples that his death and resurrection is part of God's plan and mission. Additionally, Jesus demonstrates that the kingdom of God has already come, while the eschatological banquet is not yet come. Therefore, while waiting for the consummative banquet, the believers have to embody the death and resurrection of Jesus in their lives and manifest the eschatological communion by having fellowship with the people of God regardless of their ethnicities, genders, or social status. 


\section{Bibliography}

Bauckham, Richard. Gospel Women: Studies of the Named Women in the Gospels. Grand Rapids: Eerdmans, 2002.

Betz, Hans Dieter. "Origin and Nature of Christian Faith according to the Emmaus Legend." Interpretation 23 (1969): 32-46.

Bovon, François. Luke 3: A Commentary on the Gospel of Luke 19:28-24:53. Edited by Helmut Koester and James E. Crouch. Hermeneia: A Critical and Historical Commentary on the Bible. Minneapolis: Fortress, 2012.

Bucur, Bogdan G. "Blinded by Invisible Light: Revisiting the Emmaus Story (Luke 24,13-35)." Ephemerides Theologicae Lovanienses 90.4 (2014): 685-707.

Caird, C.B. Saint Luke. New Testament Commentary. Middlesex: Penguin, 1963.

Childs, Brevard S. Exodus: A Commentary. Old Testament Library. Louisville: Westminster John Knox, 1974.

Croatto, J. Severino. "Jesus, Prophet like Elijah, and Prophet-Teacher like Moses in Luke-Acts." Journal of Biblical Literature 124.3 (2005): 451-65.

Denaux, Aderbert. "A Stranger in the City : A Contribution to the Study of the Narrative Christology in Luke's Gospel.” Louvain Studies 30.4 (2005): 255-75.

Ehrhardt, Arnold. “The Disciples of Emmaus.” New Testament Studies 10.2 (1964): 182-201.

Evans, Craig A. Luke. Peabody: Hendrickson, 1990.

Fitzmyer, Joseph A. The Gospel According to Luke. Anchor Bible 28A. Garden City: Doubleday, 2005.

Fuller, Reginald H. The Formation of the Resurrection Narratives. Minneapolis: Fortress, 2007.

Grassi, Joseph A. "Emmaus Revisited (Luke 24:13-35 and Acts 8:26-40)." The Catholic Biblical Quarterly 26.4 (1964): 463-67.

Green, Joel B. The Gospel of Luke. The New International Commentary on the New Testament. Grand Rapids: Eerdmans, 1997.

Huffman, Norman. "Emmaus among the Resurrection Narratives." Journal of Biblical Literature 64 (1945): 205-26.

Jipp, Joshua W. Divine Visitations and Hospitality to Strangers in Luke-Acts: An Interpretation of the Malta Episode in Acts 28:1-10. Supplement to Novum Testamentum 153. Leiden: Brill, 2013.

Just Jr., Arthur A. Luke. Ancient Christian Commentary on Scripture New Testament III. Downers Grove: InterVarsity, 2003.

Koenig, John. "Hospitality." ABD 3:299-301.

Laytham, D. Brent. "Interpretation on the Way to Emmaus: Jesus Performs His Story.” Journal of Theological Interpretation 1.1 (2007): 101-15. 
Leifeld, Walter L. "Luke.” Pages 797-1059 in The Expositor's Bible Commentary. Edited by Frank E. Gaebelin. Vol. 8: Matthew, Mark, Luke. Grand Rapids: Zondervan, 1984.

Marshall, I. Howard. The Gospel of Luke: A Commentary on the Greek Text. New International Commentary on the New Testament. Grand Rapids: Eerdmans, 1978.

Maxey, James. "The Road to Emmaus: Changing Expectations A Narrative-Critical Study." Currents in Theology and Mission 32.2 (2005): 112-23.

Nicholson, Ernest W. "Interpretation of Exodus 24:9-11.” Vetus Testamentum 24.1 (1974): 77-97.

Pao, David W. Acts and the Isaianic New Exodus. Wissenschafitliche Untersuchungen zum Neuen Testament 2. Reihe 130. Tübingen: Mohr Siebeck, 2000.

. "Waiters or Preachers: Acts 6:1-7 and the Lukan Table Fellowship Motif." Journal of Biblical Literature 130.1 (2011): 127-44.

Pao, David W., and Eckhard J. Schnabel. "Luke." Pages 251-414 in Commentary on the New Testament Use of the Old Testament. Edited by G.K. Beale and D.A. Carson. Grand Rapids/ Nottingham: Baker Academic, 2007.

Pitre, Brant. "Jesus, the Messianic Wedding Banquet, and the Restoration of Israel." Letter \& Spirit 8 (2012): 135-54.

Reece, S. “Seven Stades to Emmaus.” New Testament Studies 48.2 (2002): 262-66.

Robinson, Bernard P. "The Place of the Emmaus Story in Luke-Acts." New Testament Studies 30.4 (1984): 481-97.

Stein, Robert H. Luke. New American Commentary 24. Nashville: Broadman, 1992.

Tannehill, Robert C. The Narrative Unity of Luke - Acts: A Literary Interpretation. Vol. 1: The Gospel according to Luke. Philadelphia: Fortress, 1990. 